Returning after the war, Lepawsky accepted an appointment as professor of political science and public administration at the University of Alabama. His assignment involved the direction of the Southern Regional Public Service Training Program, a tri-state collaboration of the states and universities of Alabama, Kentucky, and Tennessee.

In 1953, he joined the faculty of the University of California at Berkeley, where he lectured and taught courses in public administration, public policy, planning, conservation, and ecology until his retirement in 1976, and in his retirement thereafter. Over his active career he served as a consultant to the United Nations, including a stint in 1950-51 on a technical mission to Bolivia, and as director of the United Nations Regional Training Center, and visiting professor of political science at the University of British Columbia in Vancouver in 1959-60.

A book that he wrote and edited in 1949, Administration: Art And Science of Organization and Management (Knopf, 1949) was widely used as a text. He wrote pamphlets and prepared materials for the United Nations Technical Assistance Administration for special use in developing countries. He edited, along with Edward Buehrig and Harold D. Lasswell, a book honoring Quincy Wright, The Search for World Order (Appleton, 1971). His last years were occupied in gathering materials for a major study of the New Deal, but his efforts were overtaken by declining health and death.

Albert Lepawsky held many professional, civic, and community offices, including vice president of the American Political Science Association (1956-57), president of the Western Political Science Association (1963-64), and president of the California Conservation Council (1958-60).

Albert and Rosalind Lepawsky raised their family of four children in Berkeley, a son and three daughters-Martha, Michael, Susan, and Lucy-who went to Berkeley schools. They paid their debts to the city and community of Berke- ley in many ways but most particularly through their leadership in the environmental movement and their long and successful campaign to save the bay front from commercial development. Recognizing this achievement after Albert's death, the city of Berkeley, through its mayor, Lori Hancock, issued a proclamation acknowledging the leadership of Albert and Rosalind Lepawsky " . . . of the first organized citizen effort to protect Berkeley's waterfront area from commercial development ....," without whose countless hours of dedication the preservation of the natural Berkeley waterfront would have been at serious risk.

Gabriel A. Almond
Stanford University

\section{Norton E. Long}

Norton E. Long died suddenly and quietly on December 30, 1993, at the age of eighty-three, while spending the holidays with his family. He is survived by four children (Margaret Jurich; Judith Stalling; Eliot Long; and Mary Reeves), thirteen grandchildren, four greatgrandchildren, a host of friends and admirers-and, doubtless, a few detractors for it was nearly impossible to remain neutral with respect to either his thinking or his personality.

His academic career was fairly typical of his era and locus. The son of a Harvard professor, he attended Boston Latin School, then went on to Harvard where he completed an A.B. (1932), an M.A. (1933) and a Ph.D. (1937). It appears that he spent a year in Germany, as was customary in some of the academic circles of the time, where he undoubtedly received a deeper education in the classics. He was called "Red" by his classmates; he rowed; and he once commandeered the shuttle train between Cambridge and Boston-a feat very highly regarded by his compatriots if not by the police.

Norton's professional affiliations were, as might be expected, quite varied. He was an instructor at Harvard from 1935 to 1939 , an as- sistant professor at Mount Holyoke in 1939-40, and an instructor at Queens College from 1940 to 1942. He then moved to Washington, D.C., where he remained until 1948 , first as assistant to the administrator of the Office of Price Administration (1942-46), and then as assistant administrator of the $\mathrm{Na}$ tional Housing Administration, as it was then called (1946-48).

In 1948 , he was appointed a professor of political science at Western Reserve, and remained there until 1955. In 1951, he took leave and served as special consultant to the Defense Production Administration. In 1955, he moved to Michigan State University, where he remained for four years. Then followed a five-year period as director of education at the Transportation Center at Northwestern University. During that time, he managed to serve as a special consultant, first to the Government of the Philippines (1959-61), and then to the Governor of Illinois (1961-63).

In 1964, he became chairman of the Politics Department at Brandeis University, and, among other things: a senior associate at the Harvard-M.I.T. Joint Center for Urban Studies; the director of the Institute for the Study of Violence at Brandeis; James Gordon Professor of Community Government; and finally, director of the Gordon Foundation's Municipal Internship Program. In 1968, following a row with the administration because of an unkept promise to a colleague (Gene Meehan, as it happens), he resigned and moved to the University of Illinois. In 1969, he was appointed Curators' Professor and Director of the Center for Community and Metropolitan Studies at the University of Missouri-St. Louis. He retired formally in 1981. Retirement, however, produced little change in his mode of life. He was successively a visiting professor at the University of California, Berkeley (summer 1987), at U.C. San Diego (spring 1988), at San Diego State (1989-92), and ultimately at Virginia Polytechnic Institute, where he was teaching at the time of his death.

There is no risk of overstatement in characterizing Norton Long as a 
giant in the urban politics and public administration fields. Accordingly, he was named the first recipient of the Urban Politics Section's Career Achievement Award in 1988 , and was also named the recipient of the APSA's John Gaus Award in 1991. One is less impressed by the sheer volume of his published work than by its extraordinary impact. Several of his articles became classics in the political science, public administration, and urban politics literatures, and were reprinted frequently in readers. Indeed, one of his books, The Polity (1962) was edited by Charles Press, who recognized the importance of collecting some of Norton's most influential work into one volume.

Norton's training in political theory and his background as a practicing public administrator are twin threads binding his work into a coherent whole. He understood that politics infuses all endeavors, including especially those activities undertaken by anyone claiming expertise, neutral competence, and objective knowledge. He understood that policies must reflect a balance between reasoned thinking and democratic processes. His enduring intellectual contribution and influence was to convince us all to be distrustful of reformers who claim simple answers-a compelling legacy to leave to practitioners of a discipline born of reform.

Of his many seminal articles in public administration, two particularly stand out. In a famous article published in 1949, "Power and Administration," he brilliantly dismembered the claims that there was a "science" of administration. He proposed, instead, that divorced from power, administration necessarily became an empty vessel:

There is no more forlorn spectacle in the administrative world than an agency and a program possessed of statutory life, armed with executive orders, sustained in the courts, yet stricken with paralysis and deprived of power. An object of contempt to its enemies and despair to its friends.

Lest anyone conclude his trenchant critique could be put in the service of a reactionary opposition to expertise and public administration per se, three years later he published a seminal article in the APSR ("Bureaucracy and Constitutionalism") that demonstrated how the administrative state fit firmly within the American constitutional tradition.

At a time when the study of urban government remained within the grasp of a normative tradition inherited from the Progressive Era, Norton was enormously influential in bringing politics into the literature-indeed, it may be said that he helped "father" the urban politics field, as it is currently defined. In his famous article, "The Local Community as an Ecology of Games," he cut right through the elitist-pluralist debate by proposing that local politics had a life of its own that could not necessarily be understood as the outcome of rational, calculated actions by individuals. In other words, he suggested, perhaps no one governed the city; our analytical task was, therefore, not to study the behavior of individuals, but to understand how the system as a whole operated. In his second book, The Unwalled City (1972) and in several articles, Norton explored the economic and political interdependence of urban governments years before other scholars began to appreciate how the citizens and governments of metropolitan areas were irretrievably locked into a shared fate. He asked penetrating questions about the possibilities of citizenship in a polity fractured by artificial political boundaries. Those questions now occupy scholars studying urban politics more than any other.

In his last few years Norton became concerned that public administration and the study of cities had lost all ethical moorings. In his Gaus lecture and in recent articles, he convincingly made the case for a system of social accounts that could be used to hold governments accountable. He became a sort of missionary, buttonholing friends and colleagues at conventions and in panel rooms. We can only hope that this compelling idea, like his earlier intellectual contributions, will survive him and influence the work of the next generation of scholars. One thing is sure: professional conferences will not be as interesting without his presence.

Those who knew him well will agree that Norton's greatest contribution is as a role model for others, particularly those in academia, whatever their field of specialization. Four aspects of his overall performance are particularly important to note in context. He was, first of all, an utterly honest and straightforward person-he "called them as he saw them," often to the discomfiture of those responsible for the conditions under discussion. Second, although he was a voracious reader, with an astonishingeven dismaying - capacity to recall who had said what, where, and why, few persons in academic life were as aware as he of real world constraints, or as competent in dealing with them. Third, he took a great interest in the work of younger scholars, whatever the field, and he went to considerable lengths to promote the careers of younger persons whose work he found useful and interesting-both of us are prime beneficiaries of this characteristic. Fourth, and most important of all, although he loved a good argument and hated to lose (he would fight like a tiger in any substantive discussion-whether in a chance encounter in the hallway, at a department meeting, or at an APSA panel-utterly disregarding the status, and sometimes the sensitivities, of those involved), yet when the argument ended, there were never any hard feelings or recriminations, whatever might have been said in the heat of battle-a trait perhaps made easier by the infrequency with which he "lost." In combination, these attributes contributed greatly to Norton's value as a friend, a scholar, a teacher, and a colleague.

Eugene J. Meehan

Dennis R. Judd

University of Missouri-St. Louis

\section{Grant McConnell}

One of the preeminent political scientists of mid-century, Grant McConnell, died at his home in Bonny Doon, California, on Sep- 